\title{
THE ROLE OF THE ENVIRONMENTAL IMPACT ASSESSMENT IN TERRITORIAL PLANNING
}

\author{
Marita Stradere ${ }^{1}$, Konstantins Didenko ${ }^{2}$ \\ Faculty of Engineer Economics and Management, Riga Technical University, Meza str. 1, Riga, Latvia \\ E-mails: ${ }^{1}$ mstradere@inbox.lv; ${ }^{2}$ konstantins.didenko@rtu.lv(corresponding author)
}

Received 05 March 2020; accepted 01 May 2020

\begin{abstract}
The study aim is to explore the database of economic projects. The objective is to use the data contained in the database in administrative territorial reform in Latvia. The scope of study is the register of projects in The State Environmental Bureau public data basis. The study uses data statistical analysis and comparison of economic processes methods. The study results are classified information about project location in the statistical regions as well as comparing with official statistical data about project location and statistical data on population and on building permits issued. The study confirmed the assumption that the information contained in the database of economic projects can be used as additional tool for territorial planning.
\end{abstract}

Keywords: economic project, territorial planning, environmental impact assessment.

JEL Classification: Q58, R11.

\section{Introduction}

Economic development is always linked to resource consumption and pollution caused by production, which has a negative impact on the environment (Kḷaviņš et al., 2008). Environmental regulatory frameworks, control mechanisms, appropriate various preventive actions, such as an environmental impact assessment (hereinafter referred to as EIA), authorizations for polluting activities issued are reinforced (EUR-lex, 2014). The EIA is a procedure to assess the likely impact of the implementation of the envisaged action (hereinafter "Project") on the environment, draw up proposals to prevent or reduce adverse effects, or even to prohibit the initiation of the envisaged action in cases of breaches of legal requirements whose measures can be applied in order to prevent, mitigate or eliminate adverse environmental impacts (Drenovak-Ivanović, 2016; Shparyk, 2018). Territorial planning is generally not the subject of the EIA procedure, as the planning documents apply a strategic environmental impact assessment, which has a slightly different role as an environmental impact assessment of Projects (Vircavs, 2001). The Project shall mean the introduction, replenishment or alteration of equipment, equipment and technology, the implementation of the Project, the construction, the extraction or utilization of natural resources, the development or use of human activities, undisturbed or sparking areas and landscapes, as well as other activities which may have a significant impact on the environment (Shparyk, 2018; Legal Acts of the Republic of Latvia, 1998).

In 2019, a renegotiation of current changes in the design of territorial units and the Ministry of Environmental Protection and regional development of the Republic of Latvia (hereinafter referred to "Ministry"), presented a new model for programming. The aim of the reform is to create economically strong administrative areas with local authorities to ensure the provision of quality services to the population. On 13 November 1998, the Law on Administrative reform was entered into force, with the effect of the Law on Administrative areas and settlements (31 December, 2008). In 2015, Ministry pointed shortcomings of the reform and led to change in number significantly reduced to 49 units. In 2019, the new government declaration also referred to the need complete local government reform until 2021. Currently Ministry have the solution for implementing the reform with only 35 municipalities. The criteria for new territorial units establishing are: the existence of regional or national development centers, the economic development of a sustainable territory, the attraction of investment, the development of effective structures. In 2019, Saeima of the Republic of Latvia stated that there should be following issues - justification and criteria for the establishment of national administrative areas (Legal Acts of the Republic of Latvia, 2019). 
Territorial planning is linked to territory development plans as strategic documents for individual territorial units. If a territory development plan outlines the economic vision of a territorial unit, it is necessary to take the existing social, economic, environmental situation as well as official statical data for drawing up forecasts. Since joining EU, Latvia's official statistical information about the territorial units (parishes, cities) has become too much generalized. Previous Administrative territorial reform was launched in 2009. As a result of the reform, 26 districts, including the local communities and provincial towns, were replaced by 110 counties and county towns. This meant that official statistical information on smaller territorial units was no longer provided sufficiently substantiated data for the development of the territory development plans. According to the authors of the study, the justification and criteria for establishment of new administrative areas at present are unclearly defined. Official statistical information in Latvia is compiled according to a common methodology with other ES member states. In this case we can use public available official data sources, for example, data of projects recorded during the EIA procedure. EIA is binding on projects of different character, by means of data on the place of their implementation (address), the nature of the activity, the timing, it is possible to get an idea about economic activities in small territorial units for which no official statistical data are collected.

\section{Analysis and discussion}

In Latvia, the planning of three-level territory is defined by appropriate planning documents (Legal Acts of the Republic of Latvia, 21 March, 2019):

- at national level, the Latvian Sustainable Development strategy and the National Development Plan;

- at regional level, the strategy for sustainable development of the planning region and the development programme;

- at local level, the local authority's sustainable development strategy, the development agenda, the territorial planning, the territorial planning and the remote programming level, the local authority's sustainable development strategy, the development agenda, the territorial planning, the territorial planning and the remote programming.

Territorial planning should follow the principles of (Legal Acts of the Republic of Latvia, 2011):
- the principle of sustainability: the development of the territory is intended to preserve and shape existing and future generations of quality environment, balanced economic development, rational use of natural, human and material resources, natural and cultural heritage development;

- the principle of equal opportunities: sectoral and territorial as well as private and public interests are assessed in the context of the objective of promoting the sustainable development of the area concerned;

- continuity principle: territorial development is planned in a continuous, flexible and cyclical manner, monitoring this process and evaluating the latest information, knowledge, needs and possible solutions;

- the principle of openness - in territorial planning and document drafting, involves the public and ensures the transparency of information and decision-making;

- the principle of an integrated approach economic, cultural, social and environmental aspects are coordinated, the interests of individual sectors are coordinated, the areas development priorities are coordinated at all levels of programming, the cooperation is targeted and the assessed the impact of the planned solutions on the surrounding areas and the environment;

- diversity principle: territorial development is expected taking into account the diversity of natural, cultural, human and material resources and economic activity;

- the principle of mutual harmonization: the development of territorial planning documents is developed through mutual harmonization and evaluation in other territorial planning documents.

A number of territorial development principles are linked to environmental protection principles, such as sustainable development, openness, integrated approaches and diversity. This means that both socio-economic and environmental interests are taken into account in the territory strategic planning documents.

Formally The EIA is a complex practical study that includes an assessment of the different impacts of Projects. This means that the impact of projects on geographical, hydrological, hydrogeological conditions, special areas of conservation, and the social and economic environment of the implementation site is investigated. EIA describes the intended activity site, its geographical features, such as the types of land use, the abundance of 
natural resources, the quality of regeneration, the absorption capacity of the natural environment, the density of population in the area concerned, important landscapes whose characteristics may impact the result of a project implementation. EIA is a tool with the aim to identify and evaluate the environmental impact of an action or activity in advance, to facilitating both the decision-making process and a safer environmental management (Cannaos \& Onni, 2019). Here we can see additional possibility to use EIA information in nonformal way.

Until administrative territorial reform (initiated in 2009) statistical data gave information on small territorial units, cities of the Republic and 26 regions. After the reform official statistics do not contain sufficient information about small territorial units and don not gives information about social and economic processes in them. Statistical data are generalized and this is the reason for inaccurate information for building-up new territorial units. For improving of territorial planning official statistical data can be supplemented by data from public data basis which points trends in socio-economic development as well as promote the observance of the established principles of territorial development in the process of Administrative territorial reform.

According to the study authors meaning, the environmental impact of Projects is not sufficiently evaluated. If the environmental impact of individual Projects is assessed highly detailed, there is nowhere to be taken into account the cumulative impact of projects such as the intensive construction, rebuilding, reconstruction of private houses, which will lead to a significant change in the quality of the environment. Most

Projects are allowed to realize after simple inspection and technical regulations issued by the Regional Environmental Board. Since the entry into force of the Law On Environmental Impact Assessment (13 November, 1998), a very few hundreds of Projects applied an EIA, while several thousands of Projects have only an initial environmental impact assessment and a technical regulation issued. That means the probability to find out further unknown risks to environment.

Original Project data collected by EIAs can be combined to provide a robust evidence base on which to inform development decisions (Zwart et al., 2015). The aim of this article is to represent possibility to use EIA Project data in territorial planning. The research conducted a study of the information on Projects submitted in the State Environmental Bureau Republic database for the pur- pose of using information in territorial planning (State Environmental Bureau Republic of Latvia. Environmental impact assessment. Projects). Data were taken and analyzed for four-year period from 01.01.2013 to 31.12.2016. The study restriction on project research by 01.01 .2013 . to 31.12.2016 was based on the grounds that the register of projects not eligible for the EIA was terminated by 28.02.2017, excluding the possibility of data exploration. Findings were compared with the Latvian territorial breakdown proposed in the new Administrative area model. The aim of the study is to understand possibility to use EIA Project data in territorial planning process. Study demonstrate that project data routinely collected by EIAs from multiple projects can be combined to provide a robust evidence base on which to inform development decisions.

\section{Results}

The definition of the economic activity of the Project uses the basic principles of statistical Classification of economic activities (NACE REV. 2, Regulation (EC) (Legal Acts of the Republic of Latvia, Latvia, 30 May, 2008, forfeited 6 January, 2017). Legislation rules on the common system for the classification of economic information. The study consisted of investigational features and object formulation, collection and processing of information as well as displaying and analyzing the results processed the method of comparing the statistical data processing methods, the system assessment methods. Study uses descriptive and inductive statistics methods.

Projects were classified into following groups by economic activity:

- A group "Agriculture, forestry and fisheries";

- B group "Mining and quarrying";

- C group "Manufacturing" i.e. physical or chemical transformation of materials, substances or components into new products through the substantial modification, renewal or reconstruction of goods;

- E group "Water supply; Wastewater, waste management and rehabilitation";

- F group "Construction works" i.e. buildings, reconstruction works, roads, infrastructure projects etc.;

- O group "Public administration and defense" i.e. municipal, hazardous, radioactive waste polygons, environmental protection projects etc. 
The study results were that 105 Projects $(6 \%)$ EIA procedure applied over four years, whereas the 1586 , or $94 \%$ of the EIA procedure is inappropriate, which implies the implementation of Projects only with technical regulations. From total amount there was 990 Projects from F group "Construction works" (only 50 EIA applied). That means about 58,4\% construction work Projects with significant, non-assessed impacts to environment. In the opinion of the authors, the negative impact on environmental may be possible. To the construction of private houses, the results of the study are complemented by statistical data on population numbers and on building permits issued in statistical regions. The aim was to ascertain whether there is a correlation between the construction works registered in the EIA database, the building permits issued and the population growth in administrative territorial units. Only $9 \%$ of the total number of Projects in the statistical regions of Latgale and Vidzeme are recorded. It argues that the Rìga statistical region has the lowest $6 \%$, which may indicate economical "completion" of the territory in previous years of economic activity. From 01.01.2013 to 31.12.2016 the largest number of Projects were implemented in the Pierīga statistical region, where recorded $24.36 \%$ of the projects. From the cities of the Republic the largest number of Projects recorded in Jürmala, $13.54 \%$ of the total number of projects in the reference period respectively. Lower activity is observed in Rēzekne city and Preiḷi district (see Figure 1, Figure 2, Figure 3).

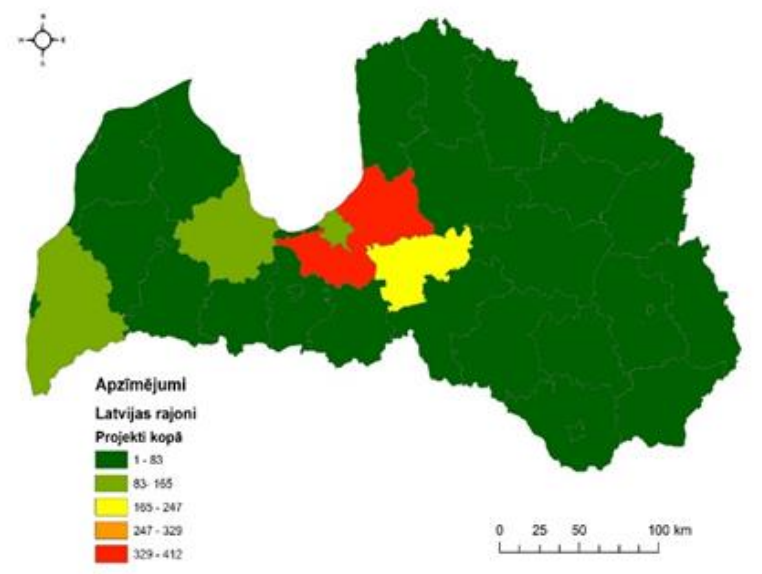

Figure 1. Territorial breakdown of Projects (source: authors according to the State Environment Bureau Republic of Latvia data, 01.01.2013 to 31.12.2016)

The Projects in red color shaded area are in the range from 329 to 412 units, with yellow color shaded projects are in the range from 165 to 247 units. Most of the country's territory belongs to the interval from 1 to 83 Projects. The concentration of Projects is expressed in the central part and affected by Kurzeme (see Figure 1, Figure 2, Figure 3). Unfortunately, Latvia has regions that are not economically binding. From a spatial planning perspective, one of the most important objectives is to anticipate how these areas could be economically developed, rather than pursuing the concentration of economic activity in the central area. There is not clear understanding why has been observed for a long time decline in certain regions, for example Latgale.

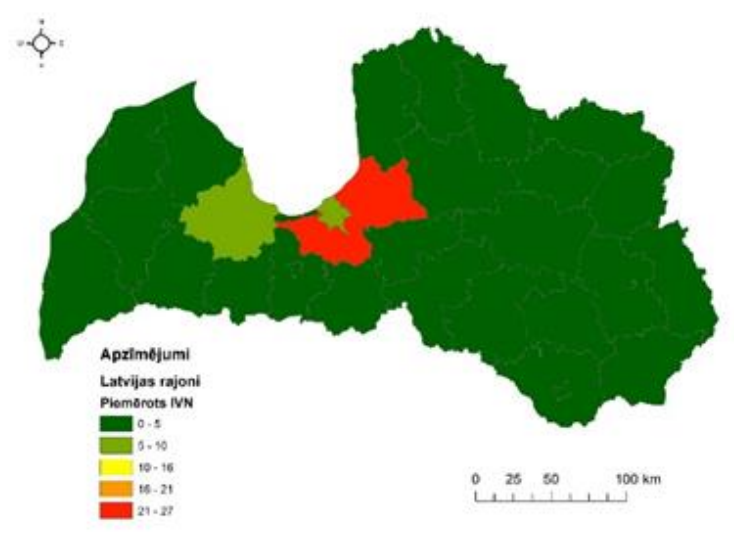

Figure 2. Projects eligible for the territorial breakdown of the EIA 2013 to 2016 (source: authors according to the State Environment Bureau Republic of Latvia data from 01.01.2013 to 31.12.2016)

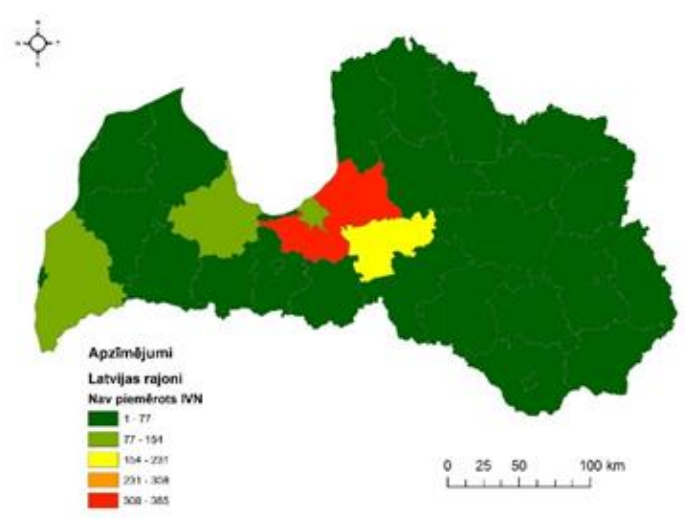

Figure 3. Projects not eligible for the territorial breakdown of the EIA from 01.01.2013 to 31.12.2016 (source: authors according to the State Environment Bureau Republic of Latvia data from 01.01.2013 to 31.12.2016)

The study showed that Project placement information is applicable to the objectives of administrative territorial reform. Assumption has been verified by the official statistical data on popula- 
tion changes and the number of building permits issued. The Central Statistical Bureau has published disclose the statistical data collected and processed by the so-called experimental statistical techniques that are not fixed, validated and internationally agreed and can be changed to improve data quality. After assessing the resident population in the cities of Republic, a picture of population change can be gained from 2000 year onwards. In Table 1. we can see population changes in 2016 on the basis of the year 2000. Calculation of the population in all specified periods is made using geospatial data-the coordinates of the address points and the boundaries of the administrative areas according to the National Land Service data on 1 January 2018. In this way, the fluctuation in the number of residents in the respective territorial unit or the administrative territory resulting from changes in the limits of territorial units. Residents whose place of residence was the reason for the last update of residence is the withdrawal of the registration of the domicile, including the population of the administrative territory in which the person was previously declared or registered. In Division of territorial units and neighborhoods of Riga, concerning Statistical Report number of resident population by gender and age in statistical regions, Cities of Republic, counties, smaller territorial units the domicile of those persons is indicated as unknown. Decrease in Jūrmala was only $11.8 \%$, in Riga at $16.2 \%$. Population decline in statistics is invested-gated from the point of emigration and immigration, but there is no direct domestic migration data in the Central Statistical Bureau.

Decrease in Jūrmala was only $11.8 \%$, in Riga at $16.2 \%$. Population decline in statistics is investigated from the point of emigration and immigration, but there is no direct domestic migration data in the Central Statistical Bureau.

It is practically impossible to trace domestic migration and, in fact, the foreign migration, since the declaration of residence is formal and does not provide information on the actual residency of the resident. In Table 1. Is possible to see population reduction in 2018. The smallest drop in population is observed in Riga and the west, at each of $0.2 \%$, while the second largest decline in the population is $2 \%$, the largest is in Venstpils 2.5\%. A statistical data on the "number of construction permits issued and the projected area per building type in the statistical regions and in the cities of the Republic" was also used to demonstrate the assumption for 4th quarter 2016. On cities of the Republic in Table 2. In statistical regions in Table 3. In the cities of the Republic group, the largest number of construction permits issued in 2016 was registered in Rīga and Jūrmala, 321 and 136 respectively.

Table 1. Changes in the number of permanent residents in the cities of the Republic 2016, 2018 (source: authors according Central Statistical Bureau)

\begin{tabular}{|c|c|c|c|c|c|}
\hline \multirow[b]{2}{*}{$\begin{array}{l}\text { City of } \\
\text { the Re- } \\
\text { public }\end{array}$} & \multicolumn{5}{|c|}{ Number of permanent residents } \\
\hline & $\begin{array}{l}2000, \\
\text { base } \\
\text { year }\end{array}$ & 2016 & $\begin{array}{l}\text { Reduc- } \\
\text { tion, \% }\end{array}$ & 2018 & $\begin{array}{l}\text { Reduc- } \\
\text { tion, \% }\end{array}$ \\
\hline$\overline{1} \mathrm{ga}$ & 762505 & & 160 & & 164 \\
\hline & 115888 & 38 & 26,2 & 83185 & 28,2 \\
\hline 1 & 6637 & 57033 & & 56475 & 1 \\
\hline $\mathrm{ka}$ & 28051 & 22578 & 19,5 & 2218 & 20, \\
\hline Jürmala & 55814 & 49247 & 11,8 & 49092 & 12,0 \\
\hline Liep & 88974 & 70613 & 20,6 & 69202 & 22,2 \\
\hline Rēzekne & 38977 & 28721 & 392 & 28154 & 27,8 \\
\hline $\begin{array}{l}\text { Valı } \\
\text { era }\end{array}$ & 27711 & 23257 & 16,1 & 23069 & 16,8 \\
\hline $\begin{array}{l}\text { Vents- } \\
\text { pils }\end{array}$ & 233 & 35964 & 18,7 & 348 & 21,2 \\
\hline Total & 11200520 & 1012308 & - & 1004034 & - \\
\hline
\end{tabular}

Table 2. The building permits issued by the cities of the Republic in 2016 the construction permits issued in the cities of the Republic 2016 (source: authors according Central Statistical Bureau)

\begin{tabular}{|l|c|c|c|}
\hline \multirow{2}{*}{ Type of building } & \multicolumn{3}{|c|}{ Issued building permits, 2016 } \\
\cline { 2 - 4 } & Latvia & Jūrmala & Rīga \\
\hline $\begin{array}{l}\text { One apartment } \\
\text { houses }\end{array}$ & 347 & 83 & 109 \\
\hline $\begin{array}{l}\text { Summer cottages } \\
\text { and garden houses }\end{array}$ & 28 & 13 & 0 \\
\hline $\begin{array}{l}\text { Two or more } \\
\text { apartment houses }\end{array}$ & 91 & 1 & 60 \\
\hline $\begin{array}{l}\text { Common using } \\
\text { houses for Various } \\
\text { social groups }\end{array}$ & 2 & 1 & 0 \\
\hline $\begin{array}{l}\text { Hotels and similar } \\
\text { use buildings }\end{array}$ & 17 & 6 & 8 \\
\hline Office buildings & 40 & 1 & 35 \\
\hline $\begin{array}{l}\text { Wholesale and re- } \\
\text { tail buildings }\end{array}$ & 37 & 0 & 29 \\
\hline $\begin{array}{l}\text { Traffic and com- } \\
\text { munication build- } \\
\text { ings }\end{array}$ & 10 & 0 & 3 \\
\hline $\begin{array}{l}\text { Industrial buildings } \\
\text { and warehouses }\end{array}$ & 54 & 1 & 25 \\
\hline
\end{tabular}


End of Table 2

\begin{tabular}{|l|c|c|c|}
\hline \multirow{2}{*}{ Type of building } & \multicolumn{3}{|c|}{ Issued building permits, 2016 } \\
\cline { 2 - 4 } & Latvia & Latvia & Latvia \\
\hline $\begin{array}{l}\text { Recreational activi- } \\
\text { ties, education, or } \\
\text { health care facili- } \\
\text { ties }\end{array}$ & 28 & 2 & 23 \\
\hline $\begin{array}{l}\text { Other non-residen- } \\
\text { tial buildings }\end{array}$ & 147 & 28 & 29 \\
\hline
\end{tabular}

Table 3. Construction permits issued in the Latvian regions in 2016 (source: authors according Central Statistical Bureau)

\begin{tabular}{|l|c|c|c|}
\hline \multirow{2}{*}{ Type of building } & \multicolumn{3}{|c|}{ Issued building permits, 2016 } \\
\cline { 2 - 4 } & Latvia & $\begin{array}{c}\text { Pierīga } \\
\text { region }\end{array}$ & $\begin{array}{c}\text { Rīga } \\
\text { region }\end{array}$ \\
\hline $\begin{array}{l}\text { Summer cottages } \\
\text { and garden houses }\end{array}$ & 189 & 117 & 0 \\
\hline $\begin{array}{l}\text { Two or more } \\
\text { apartment houses }\end{array}$ & 152 & 44 & 60 \\
\hline $\begin{array}{l}\text { Common using } \\
\text { houses for Various } \\
\text { social groups }\end{array}$ & 4 & 2 & 0 \\
\hline $\begin{array}{l}\text { Hotels and similar } \\
\text { use buildings }\end{array}$ & 42 & 14 & 8 \\
\hline Office buildings & 65 & 9 & 35 \\
\hline $\begin{array}{l}\text { Wholesale and re- } \\
\text { tail buildings }\end{array}$ & 78 & 13 & 29 \\
\hline $\begin{array}{l}\text { Traffic and commu- } \\
\text { nication buildings }\end{array}$ & 20 & 4 & 3 \\
\hline $\begin{array}{l}\text { Industrial buildings } \\
\text { and warehouses }\end{array}$ & 178 & 41 & 25 \\
\hline $\begin{array}{l}\text { Recreational activi- } \\
\text { ties, education, or } \\
\text { health care facilities }\end{array}$ & 85 & 14 & 23 \\
\hline $\begin{array}{l}\text { Other non-residen- } \\
\text { tial buildings }\end{array}$ & 1027 & 310 & 29 \\
\hline
\end{tabular}

Table 4. Scoreboard for cities of the Republic (source: authors)

\begin{tabular}{|l|c|c|c|}
\hline \multirow{2}{*}{ Region } & \multirow{2}{*}{$\begin{array}{c}\text { Issued build- } \\
\text { ing permits, } \\
2016\end{array}$} & \multicolumn{2}{|c|}{$\begin{array}{c}\text { EIA projects, } \\
\text { 2013-2016 }\end{array}$} \\
\cline { 3 - 4 } & & Number & $\%$ \\
\hline Rīga & 321 & 100 & 5.91 \\
\hline Pierīga & 1556 & 863 & 51.03 \\
\hline Vidzeme & 392 & 154 & 9.11 \\
\hline Kurzeme & 569 & 262 & 15.49 \\
\hline Zemgale & 471 & 166 & 9.82 \\
\hline Latgale & 377 & 146 & 8.63 \\
\hline Total & 3686 & 1691 & 100.00 \\
\hline
\end{tabular}

In both cases, there is observable previous trend - in the city of the Republic group is domination of Rīga and Jūrmala. Data collection on cities of the Republic is shown in Table 4. A compendium of regions could be set up on the condition that the grouping of Projects was carried out by the cities and counties of the Republic, therefore in Table 4. data on population changes and on building permits issued.

Table 5. Compilation of factors for cities of the Republic (source: authors according Central Statistical Bureau)

\begin{tabular}{|c|c|c|c|c|c|}
\hline \multirow{2}{*}{$\begin{array}{l}\text { City of } \\
\text { Republic }\end{array}$} & \multirow{2}{*}{ 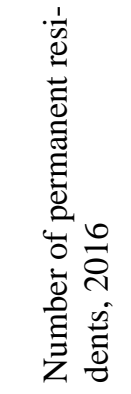 } & \multirow{2}{*}{ 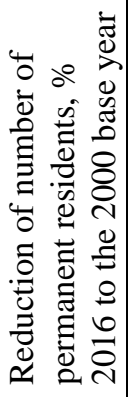 } & \multirow{2}{*}{ 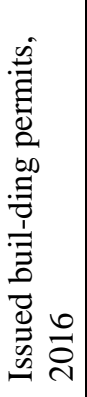 } & \multicolumn{2}{|c|}{ 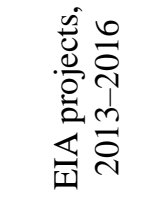 } \\
\hline & & & & 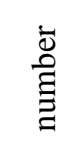 & $a^{2}$ \\
\hline Rīga & 639357 & 16,2 & 321 & 100 & 5,9 \\
\hline $\begin{array}{l}\text { Daugav- } \\
\text { pils }\end{array}$ & 85538 & 26,2 & 40 & 17 & 1,0 \\
\hline Jelgava & 57033 & 14,1 & 65 & 12 & 0,7 \\
\hline Jēkabpils & 22578 & 19,5 & 41 & $*$ & $*$ \\
\hline Jūrmala & 49247 & 11,8 & 136 & 229 & $\begin{array}{c}13 \\
5\end{array}$ \\
\hline Liepāja & 70613 & 20,6 & 44 & 16 & 0,9 \\
\hline Rēzekne & 28721 & 26,3 & 27 & 1 & 0 \\
\hline Valmiera & 23257 & 16,1 & 43 & $*$ & * \\
\hline Ventspils & 35964 & 18,7 & 84 & 26 & 1,5 \\
\hline Total & 1012308 & - & 801 & 401 & - \\
\hline
\end{tabular}

According to factors, the decline in population in 2016, the number of building permits issued in 2016, the number of Projects registered between 2013 and 2016 between the regions of the region are prevailing in Rīga and Jūrmala cities (Table 4) as well as between regions - Pierīga (Table 5).

\section{Conclusions}

1. During the implementation of the administrative territorial reform, highlight the need for development in regions with lower activity, reviewing the territorial units of the recommended areas in the context of making it more suitable to the actual situation in Latvia (see Figure 4). 


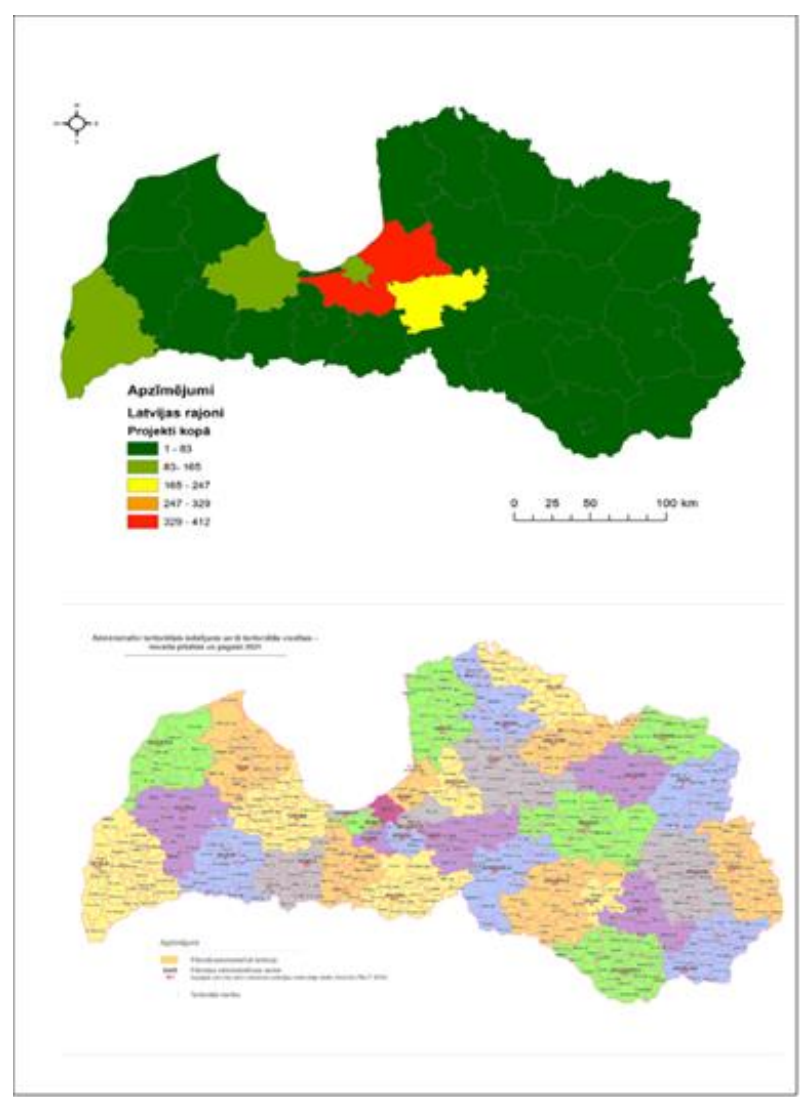

Figure 4. Comparison of the territorial placement of Projects with the Ministry model of administrative territorial reform 2019 (source: authors according to the State Environment Bureau Republic of Latvia data from 01.01.2013 to 31.12.2016 and Ministry)

2. The comparison to the Ministry new model change of administrative territorial reform with the territorial location of the Projects registered in the State Environmental Bureau Republic database is shown in Figure 4. Project placement indicates significant differences in Latvian territorial units that need to be taken into account during the future spatial planning period and during the implementation period of Administrative territorial reform.

3. From 1 January 2013 to 31 December 2016 105 projects, or $6 \%$ appropriate environmental impact assessment, while the 1586 for the project, or 94\% of the initial environmental impact assessment, is issued technical regulations.

4. Most of the projects, or $51 \%$, are recorded in the rapid statistical region, with a $39 \%$ appropriate environmental impact assessment, 52\% inappropriate, which differs significantly from the total application of environmental impact assessment in territorial units of Latvia.

5. In the cities of the Republic group most of the projects (229) are registered in Jürmala, the lowest is in Rēzekne, where only one project has been registered in period of four years.
6. The lowest drop in population in 2016 is in Rīga $16.2 \%$ and Jürmala $11.8 \%$ while the largest decline in population is observed in Rēzekne and Daugavpils, $26.3 \%$ and $26.2 \%$ respectively. The highest number of construction permits issued has been registered in Rīga and Jūrmala, with approximately half of the building permit registered in the Pierīga region.

\section{References}

Cannaos, C., \& Onni, G. (2019). A methodological approach on the procedural effectiveness of EIA: The case of Sardinia. City, Territory and Architecture, 6, 2-17. https://doi.org/10.1186/s40410-019-0100-5

Drenovak-Ivanović, M. (2016). Environmental impact assessment in Serbian legal system: Current issues and prospects for revision. Belgrade law Review, Year LXIV, No 3.2016.126.

Kḷaviņš, M., Nikodemuss, O., Segliņš, V., \& Melecis, V., Vircavs, M., \& Abolina, K. (2008). Environmental Science. University of Latvia (in Latvian).

Legal Acts of the Republic of Latvia. (1998). Law on environmental impact assessment. https://likumi.lv/doc.php?id=51522

Legal Acts of the Republic of Latvia. (1998, forfeited 2008). Law on Administrative reform. https://likumi.lv/doc.php?id=51528

Legal Acts of the Republic of Latvia. (2004). On the statistical regions of the Republic of Latvia and the administrative units within them. https://likumi.lv/ta/id/88074

Legal Acts of the Republic of Latvia. (2008). Law on Administrative areas and settlements. https://likumi.lv/ta/id/185993

Legal Acts of the Republic of Latvia. (2008). Development planning system law. https://likumi.lv/doc.php?id=175748

Legal Acts of the Republic of Latvia. (2008). Regulations regarding the uniform system for the economic information classification and procedures for introduction and use thereof. https://likumi.lv/doc.php?id=175979

Legal Acts of the Republic of Latvia. (2009). Regulations of planning region areas. https://likumi.lv/doc.php?id=191670

Legal Acts of the Republic of Latvia. (2010). Regulations regarding the classification of administrative territories and territorial units. https://m.likumi.lv/doc.php?id=207512

Legal Acts of the Republic of Latvia. (2011). Spatial Development Planning Law. https://likumi.lv/doc.php?id=238807

Legal Acts of the Republic of Latvia. (2019). On the continuation of the administratively territorial re- 
form. Retrieved May 2, 2019, from website https://likumi.lv/ta/id/305738-par-administrativiteritorialas-reformas-turpinasanu

Ministry of Environmental Protection and regional development of the Republic of Latvia. (2019). $M u$ nicipalities. Republic city and county map. Retrieved April 30, 2019, from website http://www. varam.gov.lv/lat/darbibas_veidi/pasv/

Shparyk, N. (2018). Legal regulation of environmental impact assessment in Ukraine: Current state. Journal of Vasyl Stefanyk, Precarpathian National University, 5(2), 152-162.

https://doi.org/10.15330/jpnu.5.2.152-162

State Environmental Bureau Republic of Latvia (n.d.) Environmental impact assessment. Projects. Retrieved April 21, 2019, from website http://www. vpvb.gov.lv/lv/ivn/projekti

State Environmental Bureau Republic of Latvia. (2016). Number of construction permits issued and estimated area per building type in the statistical regions and cities of the Republic. Retrieved April 21, 2019, from website https://www.csb.gov.lv/ lv/statistika/statistikas-temas/buvniecibarupnieciba-tirdznieciba/ buvnieciba/tabulas

State Statistical Bureau Republic of Latvia. (2016). Number of resident population by gender and age in statistical regions, Republican towns, counties, country towns, parishes, villages and Riga neighborhoods. Retrieved April 24, 2019, from website https://data1.csb.gov.lv/pxweb/lv/iedz/iedz__riga/ RIG010.px/table/tableViewLayout1/

The European Parliament and the Council of the European Union. (2014). Directive 2014/52/ES of the European Parliament and of the Council of 16 April 2014 amending Directive 2011/92/ES on the assessment of the effects of certain public and private projects. EUR-Lex. https://eur-lex.europa.eu/ legal-+0content/EN/TXT/?uri=celex\%3A32014 L0052In

Vircavs, M. (2001). Environmental impact assessment. Riga: Business University Turība.

Vircavs, M. (2005). Environment, impacts and assessment: Principles and analysis. Riga: Business University Turība.

Zwart, M. C., Robson, P., Rankin, S., Whittingham, M. J., \& McGowan, P. J. K. (2015). Using environmental impact assessment and postconstruction monitoring data to inform wind energy developments. Ecosphere, 6(2), 1-11. https://doi.org/10.1890/ES14-00331.1 